IZA DP No. 5228

Wage Cyclicality under Different Regimes of Industrial Relations

Hermann Gartner

Thorsten Schank

Claus Schnabel

October 2010 


\title{
Wage Cyclicality under Different Regimes of Industrial Relations
}

\author{
Hermann Gartner \\ $I A B$, Nuremberg \\ Thorsten Schank \\ University of Mainz \\ and IZA \\ Claus Schnabel \\ University of Erlangen-Nuremberg \\ and IZA
}
Discussion Paper No. 5228
October 2010

\author{
IZA \\ P.O. Box 7240 \\ 53072 Bonn \\ Germany \\ Phone: +49-228-3894-0 \\ Fax: +49-228-3894-180 \\ E-mail: iza@iza.org
}

Any opinions expressed here are those of the author(s) and not those of IZA. Research published in this series may include views on policy, but the institute itself takes no institutional policy positions.

The Institute for the Study of Labor (IZA) in Bonn is a local and virtual international research center and a place of communication between science, politics and business. IZA is an independent nonprofit organization supported by Deutsche Post Foundation. The center is associated with the University of Bonn and offers a stimulating research environment through its international network, workshops and conferences, data service, project support, research visits and doctoral program. IZA engages in (i) original and internationally competitive research in all fields of labor economics, (ii) development of policy concepts, and (iii) dissemination of research results and concepts to the interested public.

IZA Discussion Papers often represent preliminary work and are circulated to encourage discussion. Citation of such a paper should account for its provisional character. A revised version may be available directly from the author. 
IZA Discussion Paper No. 5228

October 2010

\section{ABSTRACT}

\section{Wage Cyclicality under Different Regimes of Industrial Relations*}

Since there is scant evidence on the role of industrial relations in wage cyclicality, this paper analyzes the effect of collective wage contracts and of works councils on real wage growth. Using linked employer-employee data for western Germany, we find that works councils affect wage growth only in combination with collective bargaining. Wage adjustments to positive and negative economic shocks are not always symmetric. Only under sectoral bargaining there is a (nearly symmetric) reaction to rising and falling unemployment. In contrast, wage growth in establishments without collective bargaining adjusts only to falling unemployment and is unaffected by rising unemployment.

JEL Classification: J31, E32, J53

Keywords: $\quad$ wage cyclicality, wage bargaining, works council, Germany

Corresponding author:

Claus Schnabel

Friedrich-Alexander-Universität Erlangen-Nürnberg

Lehrstuhl für Arbeitsmarkt- und Regionalpolitik

Lange Gasse 20

90403 Nürnberg

Germany

E-mail: claus.schnabel@wiso.uni-erlangen.de

\footnotetext{
* We thank Thomas Beißinger, Hans Ludsteck and participants in the 2010 Annual Congress of the Verein für Socialpolitik in Kiel as well as participants in workshops at the University of Hohenheim and at the Kiel Institute for the World Economy for their helpful comments.
} 


\section{INTRODUCTION}

Changes in (real) wages are an important vehicle for an economy's adjustment to economic shocks and play a decisive role in a wide array of macroeconomic models. Therefore discussions and investigations of wage cyclicality have a long history which goes back to Keynes (1936) and beyond. ${ }^{4}$ In recent years the response of wages to macroeconomic shocks is seen as crucial for explaining the high volatility of unemployment (see Pissarides 2009). Up to the early 1990s, most macroeconomists believed in evidence from aggregate time series showing that real wages were quite stable over the business cycle. However, Solon, Barsky and Parker (1994) demonstrated that the true movement of real wages with the business cycle is not visible in aggregate data due to a (countercyclical) composition bias. Therefore, and due to the growing availability of longitudinal micro-level data since the 1990s, attention has shifted to micro-based studies. A number of micro studies found that wages in fact change in a procyclical way and that wage cyclicality differs between different wage measures and demographic groups as well as between job stayers and employees who change employers ("movers"). ${ }^{5}$

For Germany, wage cyclicality has been investigated in three recent studies. Based on data from the German socio-economic panel, Anger (2007) finds that for the vast majority of workers within employer-employee matches hourly wages do not adjust to the business cycle, whereas monthly wages respond significantly to the cycle in various sub-samples (for instance in the private sector). The latter result is partly corroborated by Peng and Siebert (2007) who use the same data set and find real wages (including overtime payments, bonuses etc.) to be procyclical in the private sector in western Germany. Making use of a different set of data, namely the Employment Register of the Federal Employment Agency, Ludsteck (2008) compares wage adjustment in West Germany at the aggregate and regional level and shows that the latter is much smaller. Moreover, the difference in cyclical wage adjustment between stayers and movers is much greater for regional than for aggregate unemployment shocks. Ludsteck (2008) speculates that this may result from the rather centralized system of collective bargaining in Germany, but due to

4 While classical and traditional Keynesian models predict a countercyclical relationship between real wages and employment, various modern models suggest that the relationship is procyclical; for a brief discussion of the theoretical background, see Swanson (2007). A related, but more static approach is taken in the wage curve literature initiated by Blanchflower and Oswald (1994) which investigates the (negative) relationship between the levels of local unemployment and wages; for a survey, see Nijkamp and Poot (2005).

5 See, e.g., Ziliak, Wilson and Stone (1999), Shin and Solon (2007) and Swanson (2007) for the U.S., Hart (2006) and Devereux and Hart (2006, 2007) for the U.K., and Martins (2007) for Portugal. For a survey of these and other studies, see Anger (2007). 
lack of data he is not able to directly investigate the impact of wage setting institutions.

This points to a research gap which is also visible in most studies from other countries: The possibility that wage setting may differ in different bargaining regimes and that labor relations and worker representation at the firm level may also play a role is largely neglected in the literature on wage cyclicality. ${ }^{6}$ To be sure, some authors have tried to compare wage cyclicality between countries with flexible and rigid labor markets (see Peng and Siebert 2007 for a comparative study of the U.K. and western Germany), and a few studies for the U.S. have found wages of union workers to be less procyclical (see Ziliak, Wilson and Stone 1999, Grant 2003). There is just one study, however, which takes into account collective bargaining coverage: Devereux and Hart (2006) find that the wages of uncovered workers in Britain appear to be more procyclical than those of workers covered by a collective agreement, but the difference is not always statistically significant. To the best of our knowledge, there is no study which takes account of other institutional settings that may influence wage adjustments at company level, such as the existence of works councils.

Taking this research deficit as a starting point, this paper contributes to the literature on wage adjustment and wage cyclicality in three ways. First, we focus on the role of industrial relations regimes in wage adjustment by taking into account collective bargaining at the industry or firm level and the existence of companybased works councils. Second, in addition to measuring the state of the business cycle by changes in the aggregate unemployment rate we also investigate how changes in the regional unemployment rate affect wage adjustment in different industrial relations regimes and include regional fixed effects, so that we are able to distinguish between aggregate cyclical effects and regional variations of effects. Third, we distinguish between positive and negative changes in these unemployment variables, in such a way testing whether and in which regime wage cyclicality differs between recessions and expansions (as found by Martins 2007). Disaggregated analyses of this sort are possible since we use a large-scale linked employer-employee data set for western Germany which provides rich information on employees' wages and individual characteristics as well as on firm characteristics such as bargaining coverage, existence of a works council, sector and firm size.

6 This is quite surprising given the large literature on the effects of (de)centralized wage bargaining on macroeconomic performance started by Calmfors and Driffill (1988), which however has not produced clear-cut and stable empirical results; for a survey, see Aidt and Tzannatos (2002). 
The paper proceeds as follows: Section 2 explains the institutional background of wage setting in Germany and discusses the presence and the potential wage adjustment effects of various industrial relations regimes. The data and our empirical specification are described in section 3. Section 4 presents our results, and section 5 concludes.

\section{INSTITUTIONAL BACKGROUND AND THEORETICAL CONSIDERATIONS}

The German system of industrial relations is characterized by a dual system of worker representation through trade unions and works councils, extensive juridification (including co-determination at establishment and company level), encompassing organizations on both sides of the labor market, and a system of predominantly industry-level collective bargaining (for details, see Keller 2004). The constitutionally protected principle of bargaining autonomy gives organizations of employers and employees the right to regulate wages and working conditions without state interference. Collective agreements are legally binding and may be concluded either as multi-employer agreements at industry level or as singleemployer agreements at company level. Collective bargaining is mainly conducted at regional industry level, but in certain industries is quite frequent at national or company level. It determines blue and white collar pay increases (usually annually) as well as job classifications, working time, and working conditions (over longer time periods). Collectively agreed norms are minimum terms which means that companies bound by (industry- or company-level) collective agreements cannot undercut, only improve upon these terms and conditions, through voluntary premiums such as higher wages or more holidays. The concrete implementation and monitoring of industry-level collective agreements is increasingly relegated to company management and works councils.

According to the German Works Constitution Act, works councils are mandatory but not automatic in all establishments exceeding a size threshold of five permanent employees. They are not automatic in that they must be elected (by the entire workforce in the establishment). While works councils are formally independent of unions, in practice the majority of works councilors are union members. The size of the works council is fixed by law and is a function of the establishment's employment level (for more institutional details, see Addison, Schnabel and Wagner 2001). Works councils have fairly extensive rights of information (on all matters related to the discharge of their statutory functions) and consultation (on issues such as planned structural alterations to the plant and manpower planning) prescribed by law. In addition, and in contrast to continental European counterparts of workplace representation, German works councils have co-determination rights 
on what are termed "social matters". These include remuneration arrangements, the regulation of overtime and working hours, and health and safety measures. In contrast to unions, works councils may not call a strike, and they are excluded from reaching agreement with the employer on wages and working conditions that are settled or normally settled by collective agreements between unions and employer associations at industry level (unless the latter explicitly authorize works agreements of this sort). However, their extensive rights of information, consultation and co-determination on many other issues mean that works councils have considerable bargaining power which can be used for rent-seeking, and unsurprisingly effective wages have been shown to be higher in establishments with works councils (e.g. Addison, Schnabel and Wagner 2001, Hübler and Jirjahn 2003).

(Table 1 about here)

The presence and coverage of collective agreements and works councils in West Germany are shown in Table 1 based on information from the representative IAB Establishment Panel (described in detail below). It can be seen that in 1999, the starting year of our investigation, industry-level collective agreements applied in 53.4 percent of private-sector establishments with five or more employees, covering 65.6 percent of all workers. Single-employer collective agreements at firm level were found in almost 4 percent of establishments, employing about 8 percent of workers. More than 40 percent of plants and about 25 percent of employees were not covered by a collective agreement, which means that their wages and working conditions were laid down in individual contracts. The presence and coverage of collective agreements steadily rises with establishment size, and this is also the case for works councils. All in all, works councils were set up in 13.6 percent of establishments, which however employed more than 50 percent of workers. While works councils are seldom found in small establishments, they are the norm in large companies where their legal powers are much stronger. ${ }^{7}$

The presence of collective agreements and of works councils in a plant may influence wage adjustments to economic shocks in various ways. According to the theory of implicit contracts (see Azariadis 1975), risk averse workers prefer a smooth development of wages instead of a highly volatile income. In contrast, firms - in face of imperfect capital markets - may have an incentive to share risks with their employees. If institutions such as collective bargaining or works councils exist,

7 The determinants of works council existence are investigated, inter alia, by Addison et al. (2003) and Hübler and Jirjahn (2003), whereas the determinants of collective bargaining structure are studied by Hübler and Jirjahn (2003) and Schnabel, Zagelmeyer and Kohaut (2006). 
workers may have a better opportunity to prevent risks and to implement implicit contracts. A somewhat related view, expressed by Agell $(2002,108)$, would be that labor market institutions "serve an important function of social insurance". In both views, these institutions should smoothen the development of wages. In particular, we expect that a change in the unemployment rate leads (in absolute terms) to a smaller adjustment of wages if such institutions do exist.

The reaction of wages to the change in unemployment may not be symmetric, however, and whether institutions matter for the adjustment of wages may depend on the direction of the economic shock. More precisely, a Keynesian view would be that labor market institutions prevent wage cuts, resulting in downward wage rigidity (see Card and Hyslop 1997, 71). Hence, the existence of collective bargaining agreements and works councils should dampen wage adjustments to rising unemployment in order to protect workers' wages. Therefore, we should observe a non-linear relationship between changes in wages and changes in the unemployment rate in establishments with collective agreements and/or works councils. According to this view, such institutions particularly matter for the adjustment of wages if the economic situation worsens.

In the empirical analysis below, we investigate whether (and to which extent) labor market institutions such as collective bargaining and works councils do indeed matter for the adjustment of wages to economic shocks in western Germany. As indicators of changes in the economic situation, we use changes in the aggregate or regional rates of unemployment.

\section{DATA AND EMPIRICAL SPECIFICATION}

The data set used in the subsequent empirical analyses is the German LIAB, i.e. the linked employer-employee data set of the Institute for Employment Research (Institut für Arbeitsmarkt- und Berufsforschung, IAB). The LIAB combines the Employment Statistics of the German Federal Employment Agency (Bundesagentur für Arbeit) with plant-level data from the IAB Establishment Panel. For detailed information on the LIAB, see Alda, Bender and Gartner (2005).

The employee side of our data set is the Employment Statistics, covering all employees and trainees subject to social security. They exclude, among others, the self-employed, family workers, a subgroup of civil servants ("Beamte"), students enrolled in higher education, and those in marginal employment. The employment statistics cover nearly 80 percent of all employed persons in western Germany and about 85 percent of employees in eastern Germany. They are collected by the 
social insurance institutions for their purposes according to a procedure introduced in 1973 and are made available to the Federal Employment Agency. Notifications are prescribed at the beginning and at the end of a person's employment in a plant. In addition, an annual report for each employee is compulsory at the end of a year. Misreporting is legally sanctioned. The employment statistics contain information on an employee's occupation, the occupational status, and gross earnings up to the contribution assessment ceiling, as well as on individual characteristics like sex, age, nationality, and qualification. Each personnel record also contains the establishment identifier and the industry affiliation.

The employer side of our data set is given by the IAB Establishment Panel, a stratified random sample of establishments included in the Employment Statistics, where the strata are defined over industries and plant sizes (large plants are oversampled). In 1993, the panel started with 4,265 plants, covering 0.27 percent of all plants in western Germany (2 million) and 11 percent of total employment (29 million). In 1996, the establishment panel also started in eastern Germany with 4,313 establishments representing 1.1 percent of all plants $(391,000)$ and 11 percent of total employment ( 6 million). The IAB Establishment Panel has been set up for the needs of the Federal Employment Agency to provide information about the demand side of the labor market. Therefore, detailed information on the composition of the workforce and its development through time constitutes a major part of the questionnaire. Further questions concern training and further education, the total wage bill, standard hours, business activities, establishment policies, and general information about the plant like the existence of a works council and adopted bargaining agreements. With respect to the latter, plant managers are asked whether they apply a bargaining agreement (a) from the sectoral level or (b) from the firm level.

The LIAB is created by linking the Employment Statistics and the IAB Establishment Panel through the establishment identifier which is available in both data sets. Because the Employment Statistics is spell-based (one record for each employment spell), the combined data set is potentially complex. To simplify, we select all workers in the employment statistics who are employed by the surveyed plants on June 30th in a year. ${ }^{8}$ This yields an unbalanced annual panel of workers together with detailed information on the plants in which they work, which is unique for Germany.

To this data, we merge information on the registered unemployment rate obtained from the Federal Employment Agency which is calculated by dividing the reported

8 June 30th has been selected because most information in the IAB Establishment Panel refers to that date of a current year. 
number of unemployed persons at the end of June of the respective year by the sum of total unemployment and dependent civil employment. We use two different unemployment rates: (i) aggregated at the national level (of western Germany) and (ii) regional unemployment rates for 326 administrative districts (Landkreise und kreisfreie Städte - NUTS3 regions) in western Germany. This is the most disaggregated level for which labor market data are available. Therefore, we can compare whether changes in the aggregate unemployment rate and changes in (and between) the regional unemployment rate affect the adjustment of wages differently.

The dependent variable in our analysis is the change in the real wage of a worker between two consecutive years, where average daily gross wages from the Employment Statistics have been deflated by the consumer price index obtained from the Federal Statistical Office (Fachserie 17 Reihe 7). ${ }^{9}$ A shortcoming of the LIAB is that these daily gross wages are censored at the social security ceiling. ${ }^{10}$ One remedy of this data problem is to pursue single imputation, i.e. to impute the censored wages with estimated wages based on a Tobit regression (see Gartner 2005 for details). However, we are analyzing below within-person variations in the individual wage, which the Tobit procedure does not take account of. In addition, the data-generating process for wages above the social security ceiling may differ from that governing lower wages, for instance since employees in the high-wage category (such as managers) usually negotiate on their own even if the firm makes use of collective bargaining for other employees. Therefore, imputation cannot help in our context to disclose the true relationship between wages and the regressors. For this reason, we have discarded observations with censored wages. ${ }^{11}$ It should also be noted that due to the lack of information on actual hours worked, we were not able to calculate an hourly wage (which was used as the dependent variable by Peng and Siebert 2007, for example). ${ }^{12}$

9 Daily wages are calculated by dividing the reported compensation by the number of days within a spell. As noted above, our sample includes employment spells which comprise June 30th of a particular year. About three quarters of observations (and therefore also the compensation information) cover the whole year, while $98 \%$ of the spells cover at least half a year. Calculation of the average daily wage allows the comparison of wages between and within years, even for spells of different lengths.

10 The ceiling for daily gross wages in 2000 , for example, is at 143.92 Euro in western Germany.

11 This reduced our regression sample by $9.7 \%$. We have also dropped observations where reported wages were unreasonably low (i.e. wages below twice the limit for marginal workers, which is 21 Euro per day in 1998 and 26 Euro in 2005), because we reckon that in these cases either the wage or the information on working time was miscoded. This affected $1 \%$ of all observations.

12 Therefore, our dependent variable (the change in real daily wages) may vary either because the hourly wage or because hours worked have changed. However, it should be noted that the extent of paid overtime is much lower in Germany than, for example, in Britain and Japan (see Hart 2004, 13). 
We have imposed the following sample restrictions: We use the years 1999-2005 since the questions on bargaining arrangements were continuously refined until 1999. We have not included 2006 due to a break in the definition of the unemployment rate. ${ }^{13}$ Our period of observation covers a complete business cycle. From 1997 to 2001, which was the period of the new-economy boom, unemployment was falling. With the burst of the new-economy bubble in 2001 unemployment was rising again until 2005 (see Figure 1).

(Figure 1 about here)

We focus on the private sector (without agriculture) for which the employment statistics cover nearly $100 \%$ of all workers. Our analysis is based on western Germany (since the eastern German labor market is still in a special transformation process) and restricted to full-time employees, because of the lack of hours worked, such that the monthly income of part-timers cannot be compared to that of full-time employees. We restrict our analysis to wage changes of stayers, i.e. of persons who worked for the same firm in the same occupation in two consecutive years, since wage changes of movers may be due to endogenous mobility.

Finally, we only look at plants which employ between 5 and 499 employees in the first year they enter our sample frame. This is because a works council may only be elected if the plant has at least 5 employees and because almost all plants with 500 and more employees do have a works council (see Table 1). ${ }^{14}$ In addition, this restriction ensures that our results are not driven by very few large plants.

The empirical results of section 4 are based on the following equation of workerlevel changes in the real wage:

$\Delta \ln w_{i t}=\Delta u_{r t-1} \beta^{u}+\sum_{k=2}^{6} I R_{k, j t-1} \beta_{k}+\sum_{k=2}^{6} \Delta u_{r t-1} I R_{k, j t-1} \beta_{k}^{u}+Z_{i t-1} \gamma+\alpha_{r}+\varepsilon_{i t}$

13 More precisely, since the Hartz-Reform came into effect in Germany on 1 January 2005, registered unemployment is based on a wider definition because former recipients of social assistance now have to register at the local employment agencies in order to claim the new unemployment benefit II. A jump in the reported unemployment figure in January 2005 can indeed be observed (see Jacobi and Kluve (2007), who give an economic and institutional description of the German labor market before and after the Hartz-Reform). Since we use the lagged change in unemployment as a regressor in our estimation framework (see below), any change in the reported unemployment rate between 2005 and 2004 is to a considerable degree due to this redefinition and cannot be used to explain the change in individual wages between 2006 and 2005.

14 This basically means that we ignore establishments with a plant size where the distributions of establishments with and without a works council do not overlap, also known as the off-support condition. 
There are $i=1, \ldots, N$ individuals, $j=1, \ldots, J$ plants, $r=1, \ldots, R$ regions and $t=1, \ldots, T$ time periods. $\Delta$ denotes the difference operator, such that our dependent variable $\left(\Delta \ln w_{i t}=\ln w_{i t}-\ln w_{i t-1}\right)$ is the change in the real daily wage of worker $i$ between two consecutive years. $\Delta u_{r t-1}$ defines the change in the regional unemployment rate, lagged by one period. If wages adjust procyclically, then the impact of $\Delta u_{r t-1}$ on $\Delta \mathrm{In} w_{i t}$ is negative. Equation (1) assumes that the effects of rising and falling unemployment are equal, which will be relaxed in subsequent analysis. $\alpha_{r}$ is a regional fixed effect and $\varepsilon_{i t}$ captures the remaining error term. Due to the inclusion of regional fixed effects, the parameter estimate of $\beta^{u}$ is identified via within-regional variations in $\Delta u_{r t-1}$, which may be driven by regional-specific developments or by changes in the aggregate unemployment rate. We can infer which component is more important by comparing the estimate of $\beta^{\mu}$ with an estimate from an alternative specification, where $u_{r}$ is replaced by the aggregate western German unemployment rate. ${ }^{15}$

We are mainly interested in whether wage cyclicality (i.e. the impact of $\Delta u_{r t-1}$ on $\Delta \ln _{i t}$ ) varies with the prevailing institutional setting at plant level. As described in section 2, the German system of industrial relations is characterized by representation through trade unions (which bargain over wages at the sectoral or at the firm level) and through works councils, such that there are six possible combinations which could exist in a plant:

\begin{tabular}{lcc}
\hline industrial relations regimes $\left(I R_{k}\right)$ & no works council & works council \\
\hline no bargaining & 1 & 2 \\
sectoral bargaining & 3 & 4 \\
firm bargaining & 5 & 6 \\
\hline
\end{tabular}

We denote the different types of industrial relations regimes by $I R_{k}(k=1, \ldots, 6)$. The distribution of these regimes in our regression sample is reported in Appendix Table 1. It is apparent that types (1), (3) and (4) cover in each case about 30 percent of all plants, while the other regimes play only a minor role. At the individual level, as much as almost 60 percent of workers are employed by type (4) plants (sectoral bargaining, works council), reflecting the fact that this type is more likely to exist in

15 As the unemployment rate varies only at a higher level (different years respectively different regions), conventional standard error estimates should be downward biased since the error term tends to be correlated across individuals in the same year respectively in the same region. For this reason, we have clustered the standard errors at the year-level (when using the aggregated unemployment rate) respectively at the regional-level (when using the regional unemployment rate). Angrist and Pischke (2008) provide evidence that in the case of a larger number of groups using clustered standard errors is equivalent to a two-stage procedure, which has traditionally been applied in the literature on wage cyclicality (see, for example, Shin and Solon, 2007). 
large plants. In our estimation framework, we do not want to impose any restrictions a priori, and therefore allow wage cyclicality to vary between all six regimes $I R_{k}$. Hence, we include five dummy variables $I R_{k}$ and five interaction terms between the change in the unemployment rate $\Delta u_{r-1}$ and $I R_{k}(k=2, \ldots, 6)$, such that the wage cyclicality for the reference group (type 1 ) is given by $\beta^{\mu}$. Figure 2 presents the development of wage changes $\left(\Delta \ln w_{i t}\right)$ separately for the different regimes. It can be seen that wage growth is higher during boom years and lower during the recession, but at first glance there is no clear pattern concerning differences across regimes.

(Figure 2 about here)

The regressions include finally a vector of control variables $Z_{i t-1}$, which comprises the following individual and plant-level characteristics (dated at time t-1), all of which may influence the development of individual wages: dummies for gender and non-German citizenship, the potential work experience, dummies for educational attainment and 10 categories for occupational status, an indicator for the plant's production technology as well as dummies for sectoral affiliation and establishment size classes. Descriptive statistics of the dependent variable, the change in the unemployment rate and the control variables are reported in Appendix Table 2. We turn now to the results of estimating equation (1) and its modifications.

\section{EMPIRICAL RESULTS}

Tables 2 and 3 report the results of our empirical investigations. In each table, we present three models that differ in the business cycle variable used: one includes the aggregate unemployment rate (model 1 ), and the other two use the regional unemployment rate without (model 2) and with regional fixed effects (model 3). In the following, we will concentrate on the parameter estimates of the unemployment rates and the industrial relation variables as well as on their interactions without discussing the results of the control variables in detail. Suffice to say that in both tables and in all models most of the individual-level and plant-level control variables are statistically significant and show plausible signs of coefficients.

(Table 2 about here) 
Starting with Table 2, we see that in all three models changes in the unemployment rate are negatively related to yearly wage changes. ${ }^{16}$ If the aggregate unemployment rate rises by one percentage point, wage growth in the reference group (no collective bargaining and no works council) is 0.85 percentage points lower compared to the situation where unemployment remains constant. Although the effect of the aggregate unemployment rate on wage growth is much larger than the effect of the regional unemployment rate, their confidence intervals overlap. ${ }^{17}$ We should also point out that controlling for regional heterogeneity (model 3) does not change the picture further.

Looking at the industrial relation variables, it turns out that the existence of a works council does not affect wage changes if the establishment is not covered by collective bargaining. It can also be seen that collective bargaining matters: in establishments with multi-employer collective bargaining and works councils as well as in establishments with single-employer bargaining (with or without a works council), wage rises are significantly higher. Firms with collective bargaining and works councils are high-wage firms, which apparently also exhibit higher wage growth. ${ }^{18}$ Interestingly, the interactions of the change in unemployment and of the existence of collective bargaining and/or works councils do not prove to be significant in all three models. Therefore, in contrast to our expectations, firms' reactions to the business cycle are found to be the same under different regimes.

(Table 3 about here)

To investigate this surprising non-relationship between institutions and wage adjustment more closely and to allow for asymmetric reactions to changes in the unemployment rate, we now distinguish between rising and falling unemployment. The first two rows of Table 3 indicate that for the reference group (no collective bargaining, no works council) there is indeed an asymmetric reaction since the significant impact of the unemployment rate identified above only holds if unemployment falls. While a reduction in the unemployment rate is associated with a statistically significant increase in wages, the reaction of wages to a rise in

${ }^{16}$ In order to see whether it is the change in the unemployment rate or its level (as in the Phillips curve) that affects wage changes, we conducted a test proposed by Card and Hyslop (1997) in which the Phillips curve specification was clearly rejected; results are available from the authors.

17 In fact, if we use for model 1 the two-stage procedure which has been traditionally applied in the literature on wage cyclicality, the standard errors for the aggregate unemployment rate become very large such that the coefficient is statistically insignificant (while still being at -0.85 ). The difference between the clustered standard errors and the errors arising from a two-stage procedure for model 1 is due to the very low number of clusters ( 7 years) in this model.

18 This is consistent with the general increase of wage differentials in Germany observed in the last two decades (see Dustmann et al. 2009). 
unemployment proves to be insignificant. ${ }^{19}$ Looking at the interaction effects of the unemployment rates and the industrial relation dummies, it can be seen that the adjustment is significantly different for the regime with sectoral bargaining and with a works council (regime 4, which prevails in our sample). In this group of plants, wages react differently compared to the regime without bargaining and without a works council, and this holds both for reductions and for increases in unemployment.

In order to simplify the interpretation of the complex interactions parameters of (positive or negative) changes in unemployment rates and various industrial relations regimes, Figure 3 provides a simulation of the effects, which is based on the estimated coefficients of model 2 in Table 3. Taking these coefficients at face value (no matter whether they differ in a statistically significant way), we have simulated the wage change resulting from a change in the unemployment rate by one standard deviation (i.e. 1.22 percentage points). We have not included establishments with firm-level bargaining and without a works council (regime 5) due to the low number of observations in this group.

(Figure 3 about here)

Starting with the three regimes with a works council (types 2, 4 and 6, depicted by filled squares), it turns out that for stable unemployment (i.e. $\Delta$ urt-1 =0) the wage growth of workers covered by firm or sectoral bargaining (regime 4 and regime 6) is higher than that of workers not covered by collective bargaining. However, the reaction of wages to declining unemployment is lower if the establishment applies a bargaining agreement. In other words, within the group of firms with a works council an economic upswing is associated with a growth path of wages that is smoother (but starts on a higher level) if collective bargaining takes place. ${ }^{20}$

Looking at rising unemployment, we obtain two surprising results. First, we do not find a reaction of wage growth to an economic downswing in firms not bound by collective bargaining. An explanation could be that fairness considerations may lead to downward wage rigidities even in the absence of labor market institutions (see

${ }^{16}$ For model 1, the parameter estimate on reduction in the unemployment rate is very large $(-1.45)$, but again very badly determined.

20 For example, if unemployment does not change, (i.e. $\Delta u_{r t-1}=0$ ), the wage growth in plants with a works council but not covered by collective agreement amounts to 1.64 percent (setting all covariates to zero), while the respective figure is about 1 percentage point higher for plants with a works council and with a bargaining agreement at the sectoral level. However, if unemployment falls by 1.5 percentage points, say, then wage growth is exactly the same in both groups (2.9 percent). Once again, this is because wage growth reacts stronger for plants without a bargaining agreement (where it increases from 1.6 to 2.9 percent) whereas the growth path is smoother for plants with a bargaining agreement at the sectoral level (where wage growth increases only from 2.6 percent to 2.9 percent). 
Bewley 1999). Second, we find that firms with a sectoral bargaining regime do react to rising unemployment. This is in contrast to our expectations that downward rigidities are caused or reinforced by formal labor market institutions. An explanation for this observation may be the existence of opening clauses in collective contracts, which allow firms (with the consent of works councils) to deviate from sectoral agreements in order to secure jobs. In addition, more than 40 percent of plants covered by collective agreements pay wages above the level stipulated in the agreement and these so-called wage cushions can easily be reduced if the economic situation worsens (see Jung and Schnabel 2009). Taken together, there is a (nearly symmetric) reaction to rising and falling unemployment under sectoral bargaining (regime 4), but wage growth reacts asymmetrically in plants without collective bargaining (regime 2) as well as in plants with firm-level agreements (regime 6).

A reasonably similar pattern is found for the regimes without work councils (types 1 and 3 depicted by empty squares). If unemployment falls it makes no difference whether or not the firm is covered by sectoral bargaining, but if unemployment rises we again observe downward wage rigidity only in firms without collective bargaining. Similar to the regimes with works councils, we find that the reaction of wages set at sectoral level is nearly symmetric, whereas wages that are not collectively bargained (dotted line, 1) adjust asymmetrically.

Finally, we make comparisons within the same bargaining regime to assess the effect of works councils. If wages are not set by collective bargaining, works councils do not make a difference (lines 1 and 2 are close together). If wages are negotiated at sectoral level (lines 3 and 4), however, the existence of a works council leads to a higher wage growth for given unemployment and a smoother reaction if unemployment falls (the difference is statistically significant with $\mathrm{p}=0.003)$.

\section{CONCLUSIONS}

Using a large-scale linked employer-employee data set for western Germany, this paper has investigated the impact of collective bargaining and works councils on the adjustment of real wages to changes in unemployment. We find that works councils affect wage growth only in combination with collective bargaining but not in firms which make use of individual contracts. This suggests that establishmentbased works councils cannot (and do not) serve as substitutes for sectoral trade unions. We also find that wage adjustments to positive and negative economic shocks are not always symmetric. In times of declining unemployment there is a 
negative relationship between wage changes and unemployment, with wage growth being lower if the firm applies a bargaining agreement from the sectoral or the firm level. In contrast, if the economic situation worsens and unemployment rises, wages react to unemployment only if a sectoral bargaining agreement exists, whereas there are some hints on downward wage rigidity in establishments without collective bargaining and in establishment with firm-level bargaining. Hence, although the reactions to economic shocks are not as clear-cut as expected and differ between industrial relations regimes, there are some signs that labor market institutions do indeed matter for wage cyclicality.

That said, it is obvious that our paper can only be regarded as a first step towards understanding the impact of labor market institutions on wage cyclicality. Due to data limitations, we were only able to investigate the cyclicality of daily earnings, while it will be interesting to decompose fluctuations in daily earnings into changes in the hourly wage and the number of hours worked. In addition, future research should investigate more deeply the role of bargaining institutions and works councils for downward wage rigidity on the one hand and for implicit contracts on the other hand. The asymmetric reactions of wages under different industrial relations regimes found in our paper could also stimulate macroeconomic research since macroeconomic theory has largely neglected such asymmetries and the role of labor market institutions in wage adjustments. The different reactions of wages and employment across countries and industrial relations regimes in the wake of the 2008-09 world-wide economic crisis may provide an interesting field experiment for additional empirical research on wage cyclicality.

\section{REFERENCES}

Addison, J. T., Bellmann, L., Schnabel, C. and Wagner, J. (2003): German Works Councils Old and New: Incidence, Coverage and Determinants, Schmollers Jahrbuch (Journal of Applied Social Science Studies) 123, 339-358.

Addison, J. T., Schnabel, C. and Wagner, J. (2001): Works councils in Germany: their effects on establishment performance, Oxford Economic Papers 53, 659-694.

Agell, J. (2002): On the determinants of labour market institutions: Rent seeking vs. social insurance, German Economic Review 3(2), 107-135.

Aidt, T. and Tzannatos, Z. (2002): Unions and Collective Bargaining: Economic Effects in a Global Environment, Washington, D.C.

Alda, H., Bender, S. and Gartner, H. (2005): The linked employer-employee dataset created from the IAB establishment panel and the process-produced data of the 
IAB (LIAB). Schmollers Jahrbuch (Journal of Applied Social Science Studies) 125, 327-336.

Anger, S. (2007): The Cyclicality of Effective Wages within Employer-Employee Matches - Evidence from German Panel Data, ECB Working Paper No. 783, Frankfurt.

Angrist, J. and Pischke, J.-S. (2008): Mostly Harmless Econometrics, Princeton and Woodstock.

Azariadis, C. (1975): Implicit Contracts and Underemployment Equilibria, Journal of Political Economy 83(6), 1183-1202.

Bewley, T. F. (1999): Why Do Wages Not Fall During a Recession? Cambridge, Mass.

Blanchflower, D. G. and Oswald, A. J. (1994): The Wage Curve, Cambridge, Mass. and London.

Calmfors, L. and Driffill, J. (1988): Bargaining structure, corporatism and macroeconomic performance, Economic Policy 6, 13-61.

Card, D. and Hyslop, D. (1997): Does inflation grease the wheels of the labor market?, in: Romer, C. and Romer, D. (eds.), Reducing Inflation: Motivation and Strategy, NBER Studies in Business Cycles Vol. 30, Chicago, 71-121.

Devereux, P. J. and Hart, R. A. (2006): Real wage cyclicality of job stayers, withincompany job movers, and between-company job movers, Industrial and Labor Relations Review 60, 105-119.

Devereux, P. J. and Hart, R. A. (2007): The spot market matters: evidence on implicit contracts from Britain, Scottish Journal of Political Economy 54, 661-683.

Dustmann, C., Ludsteck, J. and Schönberg, U. (2009): Revisiting the German Wage Structure, Quarterly Journal of Economics 124, 843-881.

Federal Statistical Office (various issues). Verbraucherpreisindizes für Deutschland. Fachserie 17 Reihe 7. Wiesbaden.

Gartner, H. (2005): The imputation of wages above the contribution limit with the German employment sample, FDZ-Methodenreport 2/2005.

Grant, D. (2003): The Effect of Implicit Contracts on the Movement of Wages over the Business Cycle: Evidence from the National Longitudinal Surveys, Industrial and Labor Relations Review 56, 393-408.

Hart, R. A. (2004): The Economics of Overtime Working, Cambridge.

Hart, R. A. (2006): Worker-Job Matches, Job Mobility and Real Wage Cyclicality, Economica 73, 287-298. 
Hübler, O. and Jirjahn, U. (2003): Works Councils and Collective Bargaining in Germany: The Impact on Productivity and Wages, Scottish Journal of Political Economy 50, 471-491.

Jacobi, L. and Kluve, J. (2007): Before and After the Hartz Reforms: The Performance of Active Labour Market Policy in Germany, Zeitschrift für ArbeitsmarktForschung 40(1), 45-64.

Jung, S. and Schnabel, C. (2009): Paying more than necessary? The wage cushion in Germany, IZA Discussion Paper No. 4278, Bonn.

Keller, B. (2004): Employment relations in Germany, in: Bamber, G.J., Lansbury, R.D. and Wailes, N. (eds.), International and comparative employment relations. A study of industrialised market economies, 4th ed., Sydney and Singapore, 211-253.

Keynes, J. M. (1936): The General Theory of Employment, Interest and Money, London.

Ludsteck, J. (2008): Wage Cyclicality and the Wage Curve under the Microscope, IAB Discussion Paper No. 11/2008, Nuernberg.

Martins, P. S. (2007): Heterogeneity in real wage cyclicality, Scottish Journal of Political Economy 54, 684-698.

Nijkamp, P. and Poot, J. (2005): The Last Word on the Wage Curve? Journal of Economic Surveys 19(3), 421-450.

Peng, F. and Siebert, W. S. (2007): Real Wage Cyclicality in Germany and the UK: New Results Using Panel Data, IZA Discussion Paper No. 2688, Bonn.

Pissarides, C. A. (2009): The Unemployment Volatility Puzzle: Is Wage Stickiness the Answer? Econometrica 77, 1339-1369.

Schnabel, C., Zagelmeyer, S. and Kohaut, S. (2006): Collective Bargaining Structure and its Determinants: An Empirical Analysis with British and German Establishment Data, European Journal of Industrial Relations 12, 165-188.

Shin, D. and Solon, G. (2007): New Evidence on Real Wage Cyclicality within Employer-Employee Matches, Scottish Journal of Political Economy 54, 648-660.

Solon, G., Barsky, R. and Parker, J. A. (1994): Measuring the Cyclicality of Real Wages: How Important Is Composition Bias? Quarterly Journal of Economics 109, 1-26.

Swanson, E. T. (2007): Real Wage Cyclicality in the Panel Study of Income Dynamics, Scottish Journal of Political Economy 54, 617-647.

Ziliak, J. P., Wilson, B. A. and Stone, J. A. (1999): Spatial Dynamics and Heterogeneity in the Cyclicality of Real Wages, Review of Economics and Statistics 81, 227-236. 
Figure 1: Unemployment rate in western Germany

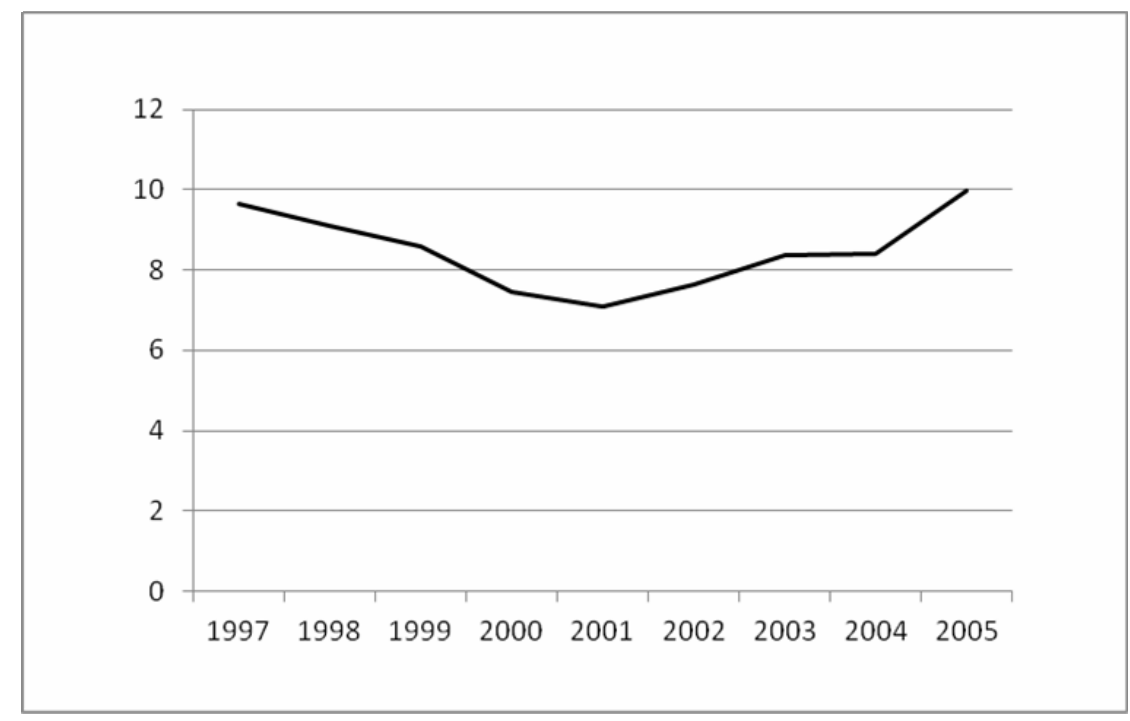

Note: Unemployment rate in June of a respective year.

Source: German Federal Labor Office. 
Figure 2: Development of real wage changes in different industrial relation regimes

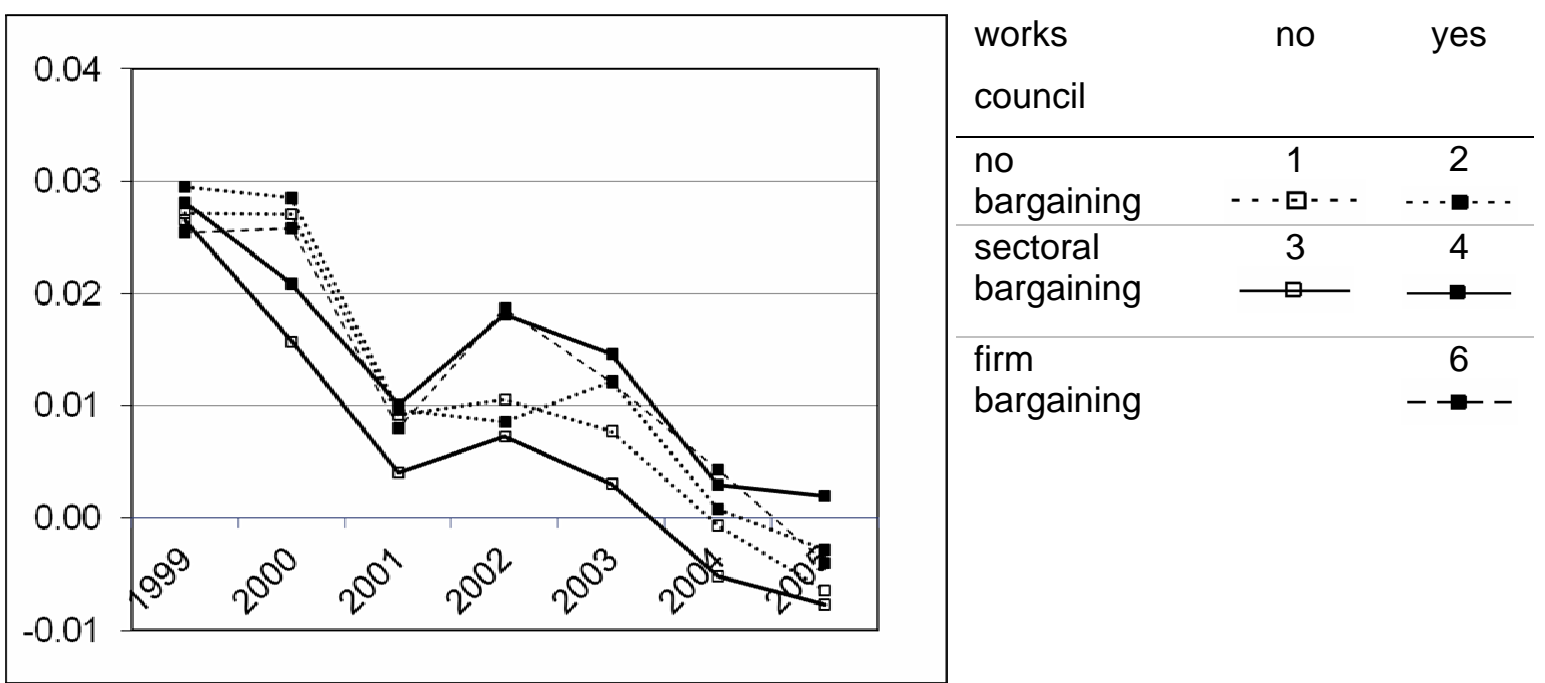

Note: Wage changes are changes between two consecutive years in log wages.

Source: LIAB, own calculations

Figure 3: Real wage changes and unemployment changes in different industrial relation regimes

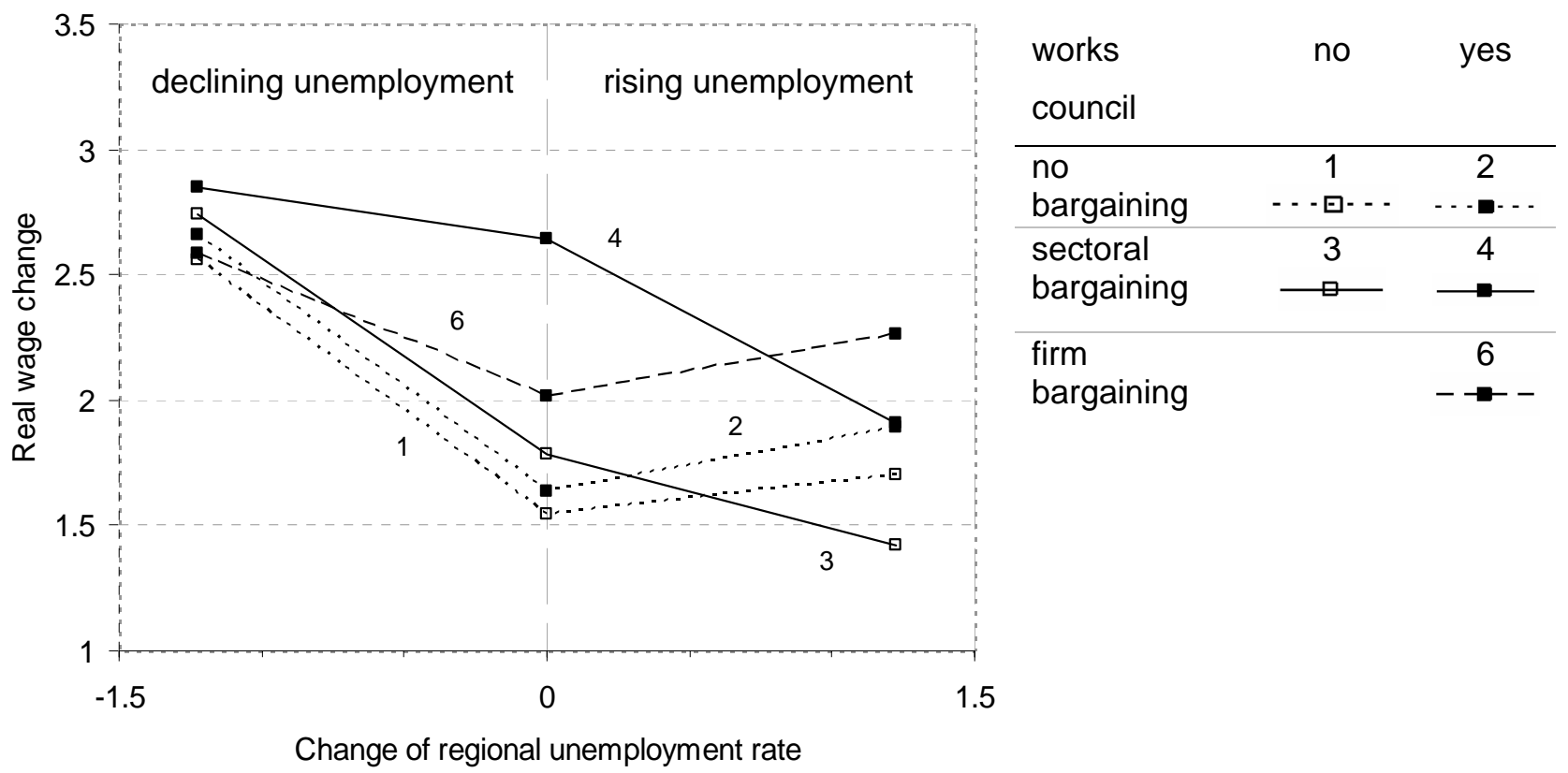

Note: Simulation of the reaction of wages (change between two consecutive years in log wages) to a change in the unemployment rate $u_{\mathrm{t}}$ based on Model 2 (Table 3) 
Table 1: $\quad$ Presence and coverage of collective agreements and works councils by establishment size in 1999; western Germany (in percent)

\begin{tabular}{|ccccccc|}
\hline $\begin{array}{l}\text { Establishment size } \\
\text { (number of } \\
\text { employees) }\end{array}$ & \multicolumn{2}{c}{$\begin{array}{l}\text { Collective agreement } \\
\text { at sectoral level }\end{array}$} & $\begin{array}{c}\text { Collective agreement } \\
\text { at firm level }\end{array}$ & \multicolumn{2}{c|}{ Works Council } \\
\hline Presence & Coverage & Presence & Coverage & Presence & Coverage \\
\hline $5-19$ & 50.2 & 50.9 & 3.0 & 3.5 & 6.2 & 7.7 \\
$20-99$ & 65.3 & 66.9 & 6.7 & 5.4 & 35.2 & 41.5 \\
$100-499$ & 67.1 & 67.9 & 10.6 & 12.4 & 75.8 & 79.5 \\
500 and above & 74.2 & 79.7 & 12.0 & 11.3 & 95.7 & 96.6 \\
Average & 53.4 & 65.6 & 3.9 & 7.9 & 13.6 & 53.7 \\
\hline
\end{tabular}

Notes: Presence refers to the share of establishments with a collective agreement respectively a works council. Coverage denotes the share of employees working in an establishment with a works council. Plants with less than five employees as well as agriculture and the public sector are excluded.

Source: IAB Establishment Panel, wave 7, 1999. 
Table 2: Determinants of individual level wage changes; OLS; western Germany (Dependent variable: change between two consecutive years in log wages)

\begin{tabular}{|c|c|c|c|}
\hline & Model 1 & Model 2 & Model 3 \\
\hline $\begin{array}{l}\text { Level of aggregation of unemployment } \\
\text { rate }\end{array}$ & national & regional & regional \\
\hline 326 Regional fixed effects & no & no & yes \\
\hline \multicolumn{4}{|l|}{ Explanatory Variables: } \\
\hline $\begin{array}{l}\text { Change in unemployment rate } \\
\text { (in \%) }\end{array}$ & $-0.8546(2.09)^{\star}$ & $-0.3964(3.35)^{\star \star \star}$ & $-0.4043(3.29)^{\star \star \star}$ \\
\hline $\begin{array}{l}\text { Bargaining agreement and works counc } \\
\text { existence (dummies) } \\
\text { (1) No bargaining/ no works council } \\
\text { (reference) }\end{array}$ & --- & --- & --- \\
\hline (2) No bargaining/ works council & $0.0013(0.94)$ & $0.0012(0.73)$ & $0.0020(1.15)$ \\
\hline $\begin{array}{l}\text { (3) Sectoral bargaining/ no works } \\
\text { council }\end{array}$ & $0.0008(0.63)$ & $0.0008(0.71)$ & $0.0008(0.63)$ \\
\hline $\begin{array}{l}\text { (4) Sectoral bargaining/ works } \\
\text { council }\end{array}$ & $0.0061(2.84)^{\star \star}$ & $0.0062(5.40)^{\star \star \star}$ & $0.0063(5.13)^{\star \star \star}$ \\
\hline (5) Firm bargaining/ no works council & $0.0103(2.74)^{\star \star}$ & $0.0113(2.98)^{\star \star \star}$ & $0.0105(2.91)^{\star \star *}$ \\
\hline (6) Firm bargaining/ works council & $0.0034(2.71)^{\star \star}$ & $0.0037(1.97)^{\star}$ & $0.0044(2.31)^{\star \star}$ \\
\hline
\end{tabular}

Change in unemployment rate interacted with ...

No bargaining/ no works council (reference)

No bargaining/ works council

Sectoral bargaining/ no works council

Sectoral bargaining/ works council

Firm bargaining/ no works council

Firm bargaining/ works council

New production technology (dummy)

Missing information on production

technology (dummy) $0.0037(1.97)^{\star}$

Female (Dummy)

Foreign Citizenship (Dummy)

Potential work experience (in years)

Educational attainment dummies (ref. group: without apprenticeship or Abitur)

Apprenticeship, no Abitur

No Apprenticeship, with Abitur

Apprenticeship and Abitur

Technical college degree

University degree

Education unknown

Occupational dummies (ref. group: basic manual occupation)

Qualified manual occupation

Engineer, technician

Basic service occupation

$\begin{array}{rrrr}-0.0017(3.49)^{\star \star} & -0.0017(3.25)^{\star \star \star} & -0.0020(4.24)^{\star \star \star} \\ 0.0077(8.72)^{\star \star \star} & 0.0076(4.66)^{\star \star \star} & 0.0068(4.15)^{\star \star \star} \\ 0.0029(3.72)^{\star \star \star} & 0.0028(3.25)^{\star \star \star} & 0.0023(2.82)^{\star \star \star} \\ 0.0047(3.94)^{\star \star \star} & 0.0046(5.16)^{\star \star \star} & 0.0038(4.62)^{\star \star \star} \\ 0.0022(2.43)^{\star} & 0.0022(1.27) & 0.0013(0.79) \\ -0.0257(12.1)^{\star \star \star} & -0.0254(21.1)^{\star \star \star} & -0.0260(23.0)^{\star \star \star} \\ & & & \\ & & & \\ -0.0008(0.54) & -0.0008(1.32) & -0.0009(1.62) \\ 0.0066(4.77)^{\star \star \star} & 0.0066(9.27)^{\star \star \star} & 0.0064(9.69)^{\star \star \star} \\ -0.0016(1.73) & -0.0016(2.04)^{\star \star} & -0.0013(1.76)^{\star}\end{array}$

\begin{tabular}{ccl}
\multicolumn{1}{c}{--} & \multicolumn{1}{c}{---} & \multicolumn{1}{c}{--} \\
$0.0263(0.21)$ & $0.0606(0.31)$ & $0.1262(0.65)$ \\
$-0.1270(0.92)$ & $-0.1622(1.07)$ & $-0.1149(0.76)$ \\
$0.1561(0.73)$ & $0.0368(0.29)$ & $0.0918(0.71)$ \\
$0.0984(0.21)$ & $0.2560(0.47)$ & $0.3130(0.61)$ \\
$0.1094(1.00)$ & $0.2004(0.86)$ & $0.2727(1.13)$ \\
\hline $0.0026(2.49)^{\star \star}$ & $0.0027(3.74)^{\star \star \star}$ & $0.0025(3.36)^{\star \star \star}$ \\
$0.0050(3.29)^{\star \star}$ & $0.0033(1.08)$ & $0.0020(0.60)$ \\
\hline$-0.0014(2.97)^{\star \star}$ & $-0.0013(2.80)^{\star \star \star}$ & $-0.0015(3.52)^{\star \star \star}$ \\
$-0.0015(2.03)^{\star}$ & $-0.0014(2.51)^{\star \star}$ & $-0.0018(3.36)^{\star \star \star}$ \\
$-0.0010(15.5)^{\star \star \star}$ & $-0.0010(43.9)^{\star \star \star}$ & $-0.0010(45.4)^{\star \star \star}$
\end{tabular}

$-0.0010(15.5)^{\star \star \star}$

$-0.0010(43.9)^{\star \star \star}$

$0.0010(45.4)^{\star \star \star}$ 


\begin{tabular}{lcll} 
Qualified service occupation & $-0.0042(0.76)$ & $-0.0041(0.95)$ & $-0.0050(1.08)$ \\
Semi-professional & $0.0044(1.11)$ & $0.0042(0.92)$ & $0.0037(0.79)$ \\
Professional & $0.0073(2.28)^{\star}$ & $0.0074(2.87)^{\star \star \star}$ & $0.0077(3.25)^{\star \star \star}$ \\
Basic business occupation & $0.0025(1.47)$ & $0.0024(2.41)^{\star \star}$ & $0.0026(2.62)^{\star \star \star}$ \\
Qualified business occupation & $0.0099(6.66)^{\star \star \star}$ & $0.0098(13.4)^{\star \star \star}$ & $0.0098(14.9)^{\star \star \star}$ \\
Manager & $0.0078(2.68)^{\star \star}$ & $0.0078(5.41)^{\star \star \star}$ & $0.0081(5.84)^{\star \star \star}$ \\
Constant & & & \\
\hline $\mathrm{R}^{2}$ & $0.0201(5.34)^{\star \star \star}$ & $0.0186(6.40)^{\star \star \star}$ & $0.0202(5.51)^{\star \star \star}$ \\
\hline
\end{tabular}

Notes: 882,576 observations from 6,815 plants in each regression. Regressions also include dummies for 8 sectors and 9 plant size classes. |t|-statistics in parentheses, based on robust standard errors adjusted for clustering at the year- (Model 1 ) respectively at the regional-level (Models 2 and 3). The sample comprises the years 1999-2005. 
Table 3: Determinants of individual level wage changes; OLS; western Germany; asymmetric effects of positive and negative changes in the unemployment rate (Dependent variable: change between two consecutive years in log wages)

\begin{tabular}{|c|c|c|c|}
\hline & Model 1 & Model 2 & Model 3 \\
\hline $\begin{array}{l}\text { Level of aggregation of unemployment } \\
\text { rate }\end{array}$ & national & regional & regional \\
\hline 326 Regional fixed effects & no & no & yes \\
\hline \multicolumn{4}{|l|}{ Explanatory Variables: } \\
\hline $\begin{array}{l}\text { Change in unemployment rate } \\
\text { (in \%) } x \text { dummy change positive }\end{array}$ & $-0.0131(0.01)$ & $0.1256(0.56)$ & $0.0534(0.23)$ \\
\hline $\begin{array}{l}\text { Change in unemployment rate } \\
\text { (in \%) } x \text { dummy change negative }\end{array}$ & $-1.4562(1.16)$ & $-0.8281(3.43)^{\star \star \star}$ & $-0.7882(3.23)^{\star \star \star}$ \\
\hline \multicolumn{4}{|l|}{$\begin{array}{l}\text { Bargaining agreement and works council } \\
\text { existence (dummies) }\end{array}$} \\
\hline $\begin{array}{l}\text { (1) No bargaining/ no works council } \\
\text { (reference) }\end{array}$ & --- & --- & --- \\
\hline (2) No bargaining/ works council & $0.0008(0.36)$ & $0.0009(0.31)$ & $0.0021(0.66)$ \\
\hline $\begin{array}{l}\text { (3) Sectoral bargaining/ no works } \\
\text { council }\end{array}$ & $0.0032(3.32)^{\star \star}$ & $0.0024(1.14)$ & $0.0022(1.01)$ \\
\hline $\begin{array}{l}\text { (4) Sectoral bargaining/ works } \\
\text { council }\end{array}$ & $0.0115(7.53)^{\star \star \star}$ & $0.0109(5.39)^{\star \star \star}$ & $0.0111(5.26)^{\star \star \star}$ \\
\hline (5) Firm bargaining/ no works council & $0.0091(1.14)$ & $0.0206(3.15)^{\star \star \star}$ & $0.0215(3.55)^{\star \star \star}$ \\
\hline (6) Firm bargaining/ works council & $0.0046(1.71)$ & $0.0047(1.46)$ & $0.0053(1.59)$ \\
\hline \multicolumn{4}{|l|}{$\begin{array}{l}\text { Change in unemployment rate } \\
\text { (in \%) } x \text { dummy change positive } \\
\text { interacted with ... }\end{array}$} \\
\hline $\begin{array}{l}\text { No bargaining/ no works council } \\
\text { (reference) }\end{array}$ & --- & --- & --- \\
\hline No bargaining/ works council & $0.0851(0.23)$ & $0.0830(0.20)$ & $0.0941(0.22)$ \\
\hline $\begin{array}{l}\text { Sectoral bargaining/ no works } \\
\text { Council }\end{array}$ & $-0.7067(2.86)^{\star \star}$ & $-0.4273(1.50)$ & $-0.3550(1.23)$ \\
\hline $\begin{array}{l}\text { Sectoral bargaining/ works } \\
\text { council }\end{array}$ & $-1.1262(6.23)^{\star \star \star}$ & $-0.7260(2.93)^{\star \star \star}$ & $-0.6836(2.75)^{\star \star \star}$ \\
\hline Firm bargaining/ no works council & $0.4174(0.24)$ & $-1.3956(1.69)^{\star}$ & $-1.6987(1.97)^{\star}$ \\
\hline Firm bargaining/ works council & $-0.1545(0.40)$ & $0.0755(0.12)$ & $0.1625(0.26)$ \\
\hline
\end{tabular}

Change in unemployment rate

(in \%) $x$ dummy change negative

interacted with ...

No bargaining/ no works council (reference)

No bargaining/ works council

Sectoral bargaining/ no works

Council

Sectoral bargaining/ works council

Firm bargaining/ no works council

Firm bargaining/ works council

New production technology (dummy)

Missing information on production

technology (dummy)

Female (Dummy)

Foreign Citizenship (Dummy)

Potential work experience (in years)

Educational attainment dummies (ref.

\begin{tabular}{lll}
$c$ & \multicolumn{1}{c}{--} & \multicolumn{1}{c}{--} \\
$-0.0627(0.35)$ & $-0.0091(0.03)$ & $0.1142(0.33)$ \\
$0.2840(3.07)^{\star \star}$ & $0.0470(0.17)$ & $0.0802(0.28)$ \\
$1.0660(4.66)^{\star \star \star}$ & $0.6590(2.51)^{\star \star}$ & $0.7246(2.76)^{\star \star \star}$ \\
$0.0305(0.03)$ & $1.3371(1.73)^{\star}$ & $1.6068(2.48)^{\star \star}$ \\
$0.3163(1.26)$ & $0.3670(0.99)$ & $0.4132(1.09)$ \\
\hline $0.0026(2.59)^{\star \star}$ & $0.0028(3.81)^{\star \star \star}$ & $0.0026(3.47)^{\star \star \star}$ \\
$0.0046(2.29)^{\star}$ & $0.0034(1.10)$ & $0.0020(0.60)$ \\
\hline$-0.0014(2.82)^{\star \star}$ & $-0.0013(2.82)^{\star \star \star}$ & $-0.0015(3.50)^{\star \star \star}$ \\
$-0.0015(2.10)^{\star}$ & $-0.0014(2.58)^{\star \star}$ & $-0.0018(3.40)^{\star \star \star}$ \\
$-0.0010(17.1)^{\star \star \star}$ & $-0.0010(44.3)^{\star \star \star}$ & $-0.0010(45.8)^{\star \star \star}$
\end{tabular}


group: without apprenticeship or Abitur)

Apprenticeship, no Abitur
No Apprenticeship, with Abitur
Apprenticeship and Abitur
Technical college degree
University degree
Education unknown

$\begin{array}{rrrr}-0.0017(3.69)^{\star \star} & -0.0017(3.29)^{\star \star \star} & -0.0020(4.27)^{\star \star \star} \\ 0.0077(8.74)^{\star \star \star} & 0.0076(4.67)^{\star \star \star} & 0.0068(4.15)^{\star \star \star} \\ 0.0029(3.76)^{\star \star \star} & 0.0028(3.26)^{\star \star \star} & 0.0023(2.84)^{\star \star \star} \\ 0.0046(3.90)^{\star \star \star} & 0.0046(5.12)^{\star \star \star} & 0.0038(4.59)^{\star \star \star} \\ 0.0022(2.42)^{\star} & 0.0021(1.23) & 0.0012(0.77) \\ -0.0257(12.6)^{\star \star \star} & -0.0256(21.1)^{\star \star \star} & -0.0261(22.9)^{\star \star \star}\end{array}$

Occupational dummies (ref. group: basic manual occupation)

\begin{tabular}{lccc} 
Qualified manual occupation & $-0.0008(0.54)$ & $-0.0008(1.27)$ & $-0.0009(1.59)$ \\
Engineer, technician & $0.0066(4.81)^{\star \star \star}$ & $0.0066(9.30)^{\star \star \star}$ & $0.0065(9.76)^{\star \star \star}$ \\
Basic service occupation & $-0.0015(1.71)$ & $-0.0015(1.92)^{\star}$ & $-0.0012(1.64)$ \\
Qualified service occupation & $-0.0042(0.76)$ & $-0.0042(0.97)$ & $-0.0051(1.17)$ \\
Semi-professional & $0.0044(1.11)$ & $0.0042(0.89)$ & $0.0037(0.79)$ \\
Professional & $0.0074(2.27)^{\star}$ & $0.0074(2.89)^{\star \star \star}$ & $0.0078(3.27)^{\star \star \star}$ \\
Basic business occupation & $0.0025(1.53)$ & $0.0024(2.38)^{\star \star}$ & $0.0025(2.60)^{\star \star \star}$ \\
Qualified business occupation & $0.0099(6.92)^{\star \star \star}$ & $0.0098(13.4)^{\star \star \star}$ & $0.0098(14.9)^{\star \star \star}$ \\
Manager & $0.0078(2.66)^{\star \star}$ & $0.0077(5.51)^{\star \star \star}$ & $0.0081(5.91)^{\star \star \star}$ \\
& & & \\
Constant & $0.0166(2.91)^{\star \star}$ & $0.0155(4.81)^{\star \star \star}$ & $0.0172(4.32)^{\star \star \star}$ \\
\hline $\mathrm{R}^{2}$ & 0.0244 & 0.0230 & 0.0229 \\
\hline
\end{tabular}

Notes: 882,576 observations from 6,815 plants in each regression. Regressions also include dummies for 8 sectors and 9 plant size classes. |t|-statistics in parentheses, based on robust standard errors adjusted for clustering at the year- (Model 1 ) respectively at the regional-level (Models 2 and 3). The sample comprises the years 1999-2005. 


\section{APPENDIX}

Appendix Table 1: Regression sample by bargaining agreements and works council existence

\begin{tabular}{lcccc}
\hline \multirow{2}{*}{$\begin{array}{l}\text { Industrial relations } \\
\text { regimes }\end{array}$} & Observations & Frequency (\%) & Observations & Frequency (\%) \\
\hline $\begin{array}{l}\text { (1) No bargaining/ } \\
\text { no works council }\end{array}$ & 100,268 & 11.36 & 3,956 & 27.07 \\
$\begin{array}{l}\text { (2) No bargaining/ } \\
\text { works council }\end{array}$ & 90,410 & 10.24 & 884 & 6.05 \\
$\begin{array}{l}\text { (3) } \begin{array}{l}\text { Sectoral bargaining/ } \\
\text { no works council }\end{array} \\
\begin{array}{l}\text { (4) Sectoral bargaining/ } \\
\text { works council }\end{array}\end{array}$ & 99,473 & 11.27 & 4,468 & 30.57 \\
(5) Firm bargaining/ & 503,341 & 57.03 & 4,436 & 30.35 \\
no works council & 5,445 & 0.62 & 156 & 1.07 \\
(6) Firm bargaining/ & 83,639 & 9.48 & 716 & 4.90 \\
\hline works council & & & & \\
\hline
\end{tabular}


Appendix Table 2: Descriptive Statistics of regression sample

\begin{tabular}{|c|c|}
\hline Variables & Mean Std.Dev \\
\hline Change (between two years) in log wages & 0.0250 .082 \\
\hline $\begin{array}{l}\text { Change in regional unemployment rate (in \%) } \\
\text { Change in regional unemployment rate (in \%) } x \\
\text { dummy change positive } \\
\text { Change in regional unemployment rate (in \%) } x \\
\text { dummy change negative }\end{array}$ & $\begin{array}{r}-0.0010 .009 \\
0.0030 .005 \\
-0.0040 .005 \\
\end{array}$ \\
\hline Plant size (number of employees) & $230,955178,044$ \\
\hline New production technology (dummy) & 0.7150 .452 \\
\hline Missing information on production technology (dummy) & 0.0100 .099 \\
\hline Female (dummy) & 0.2520 .434 \\
\hline Foreign Citizenship (dummy) & 0.0930 .291 \\
\hline Potential work experience (in years) & 23.83210 .917 \\
\hline \multicolumn{2}{|l|}{ Educational attainment dummies } \\
\hline Without apprenticeship or Abitur & 0.1850 .388 \\
\hline Apprenticeship, no Abitur & 0.6630 .473 \\
\hline No Apprenticeship, with Abitur & 0.0060 .079 \\
\hline Apprenticeship and Abitur & 0.0440 .204 \\
\hline Technical college degree & 0.0220 .148 \\
\hline University degree & 0.0180 .132 \\
\hline Education unknown & 0.0620 .242 \\
\hline \multicolumn{2}{|l|}{ Occupational dummies } \\
\hline Basic manual occupation & 0.2950 .456 \\
\hline Qualified manual occupation & 0.2260 .418 \\
\hline Engineer, technician & 0.0850 .278 \\
\hline Basic service occupation & 0.1090 .311 \\
\hline Qualified service occupation & 0.0050 .067 \\
\hline Semi-professional & 0.0020 .050 \\
\hline Professional & 0.0040 .063 \\
\hline Basic business occupation & 0.0490 .216 \\
\hline Qualified business occupation & 0.2160 .412 \\
\hline Manager & 0.0100 .099 \\
\hline Observations & 882,576 \\
\hline
\end{tabular}

